\title{
Hiring older people as a way to increase diversity and improve the quality of society
}

\author{
Marjeta Logar Čuček \\ Ljubljana University Medical Centre, Department of Oral and Maxillofacial Surgery, \\ Zaloška cesta 2, 1000 Ljubljana, Slovenia \\ marjetalogar@gmail.com
}

\begin{abstract}
Introduction: The co-called »new reality«, as observed both in Slovenia and abroad, does not favour the employment of older population. Older people, who are still active, are labelled as high-risk groups that need special health care. The society expects an active participation of every individual- being knowledgeable about the world, understanding the events and environment leads us to value expertize, work experience and critical reasoning of older employees. They need to be given an active role, but not under conditions that drive a worker into absenteeism, failing to appear at work, even without health reasons, or presenteeism, being present at work at all costs. The latter, in particular, should not be admissible. The current situation clearly shows that each individual should be able to, if they fall ill, quarantine themselves. An employee who understands when their behaviour might endanger others, should never be dismissed by an employer as old or useless. The purpose of this study is to find out to what extent the two phenomena have been researched at the post-graduate level at medical faculties, faculty of health sciences or health care faculties in Slovenia, considering various risk factors present at work and maintaining effort to extend the years of service of older employees. Methods: Master's and Doctoral theses from chosen faculties, published online between 2015 and 20202, have been studied by using the PRISM protocol. The identified hits have been described, analysed and evaluated. Results: Abstenteeism has been researched in different postgraduate study programmes, including health studies, whereas presenteeism, which is increasingly observed in current time, has so far not been dealt with in the scope that would provide a more thorough insight into finding solutions. The employment of older population is presented in the sense of maintaining their physical fitness, partially also as a stress-coping mechanism. The influences of other psychosocial factors still remain insufficiently explored, considering the
\end{abstract}


complexity of the issue. Discussion and conclusion: Both absenteeism and presenteeism are frequently the result of a fear of the »impossible« or »loss«. The changes in society are more often than not dependent on the changes in an individual's value system. New values slowly but surely take root in all pores of society; the process is greatly accelerated by development and science. The research into the consequences of aging society and longevity and the growing importance of employment of older population has so far not been widely conducted on the academic level and, consequently, changes and improvements have not been implemented in real life yet. Monitoring and analysing of improvements are of vital importance. The improvements that have already been achieved in the field of equal treatment of older people in employment can be cancelled out, sometimes very subtly, by a change on the global, or even local level. Activities intended to increase the years of service of older population should, therefore, not be pushed aside as less important. Diversity, as a key characteristic of humanity, even in the golden years, leads to outstanding results and higher quality of life.

Keywords: employment, working conditions, excessive workload, presenteeism, absenteeism

\section{Introduction}

Increasing the duration and improving the employment of older population has until recently been a goal of economic entities and political decision. This has led to the need to increase the period of active service due to the fact that older employees, who can draw on the knowledge and experience obtained over several decades, have a desire to learn and are able to adapt to the new economic circumstances, are of vital importance to active and productive society (Novoselc, 2019; Logar Čuček, 2020).

At the moment, the so-called »new normal«, resulting from the consequences of the epidemics and the consequent economic downturn, both at home and abroad, significantly contributes to increasingly unfavourable conditions for older population since longer employment is not encouraged. The principle of lower market flexibility and higher job protection is coming into the foreground, together with lowering the percentage of precarious jobs (Gaspari, 2020), which could also mean encouraging older employees to retire. The companies that make use of the so-called exit strategies, i.e. early retirement and lay-offs, tend to fall behind those that are successful in overcoming demographic and competition challenges (Van Dalen et al., 2015). Identifying job risk factors and their mitigation, creating the culture of health and good work, together with adapting working hours and job accessibility, all lead to the creation of jobs that are beneficial for all age groups and not only for older population (Tratnik, 2019).

Frequently employees cope with the pressure at work, by absenteeism or absence from work, or presenteeism, coming to work despite the need for re- 
cuperation (Logar, 2011; Logar Čuček, 2020). There are many sides to absenteeism, owing to that fact that it is practised by humans. Employees stay away from work from a variety of reasons (Kirkham et al., 2015). To a smaller extent, absenteeism is the result of non-medical reasons which are often manifested as justifiable absence from work (Bilban, 2007). No matter what form absenteeism takes, its reasons and duration, it can decrease the activity of older employees and consequently lead to premature retirement (Wargo-Sugleris et al, 2017).

Presenteeism is one of the "side-ways « of management. Many organisations wrongly assume that a low level of sick leave signifies good employee health. Consequently, employees appear in their workplaces despite being ill, feeling unwell, suffering from psychological problems. Many of them are worried about their job security and are not willing to take risks - especially people with families and those just a couple of years before retirement (Lalič and Hromin, 2012). In some employees, presenteeism is a matter of individual decision (Brečko 2012; Boštjančič and Sajinčič, 2016).

The purpose of reviewing published materials at the post-graduate levels at three medical faculties in Slovenia was to study Master's theses and Doctoral dissertations that deal with the phenomena of absenteeism and presenteeism in older employees.

The objective of the study was to ascertain to what extent the phenomena of absenteeism and presenteeism of older employees are studied in Slovenia at health-related institutions and to prepare suggestions for such research.

The research question posed was: What is the purpose and role of post-graduate research on the influence of absenteeism and presenteeism on older employees?

\section{Methods}

\section{Review methods}

A review of Master's theses and Doctoral dissertations, published online between 2015 and 2020, was used. Faculty databases were chosen for finding references since the objective was to find out to what extent the area of older employees is researched at the post-graduate level. The following combinations of key words in Slovene language were used as search entries: older employees, employment of older populations, absenteeism and presenteeism in older employees; later on, words which represent the conditions for successful work of different generations, such as promotion of health, lifelong learning were added. The search was carried out in the period between May 2020 and June 2020. The search was limited by the following inclusion and exclusion criteria: search period between 2015 and 2020, Slovene language, and freely available data. 


\section{Review results}

Database search strategy came up with 66 hits. After checking their relevance, 20 hits were excluded. According to content relevance, 46 hits were obtained. After considering all limiting criteria, 6 hits were used for final reference. Figure 1 shows searching for Master's theses and Doctoral dissertations. A schematic presentation has been used, as enabled by PRISM scheme (Moher et al., 2009).
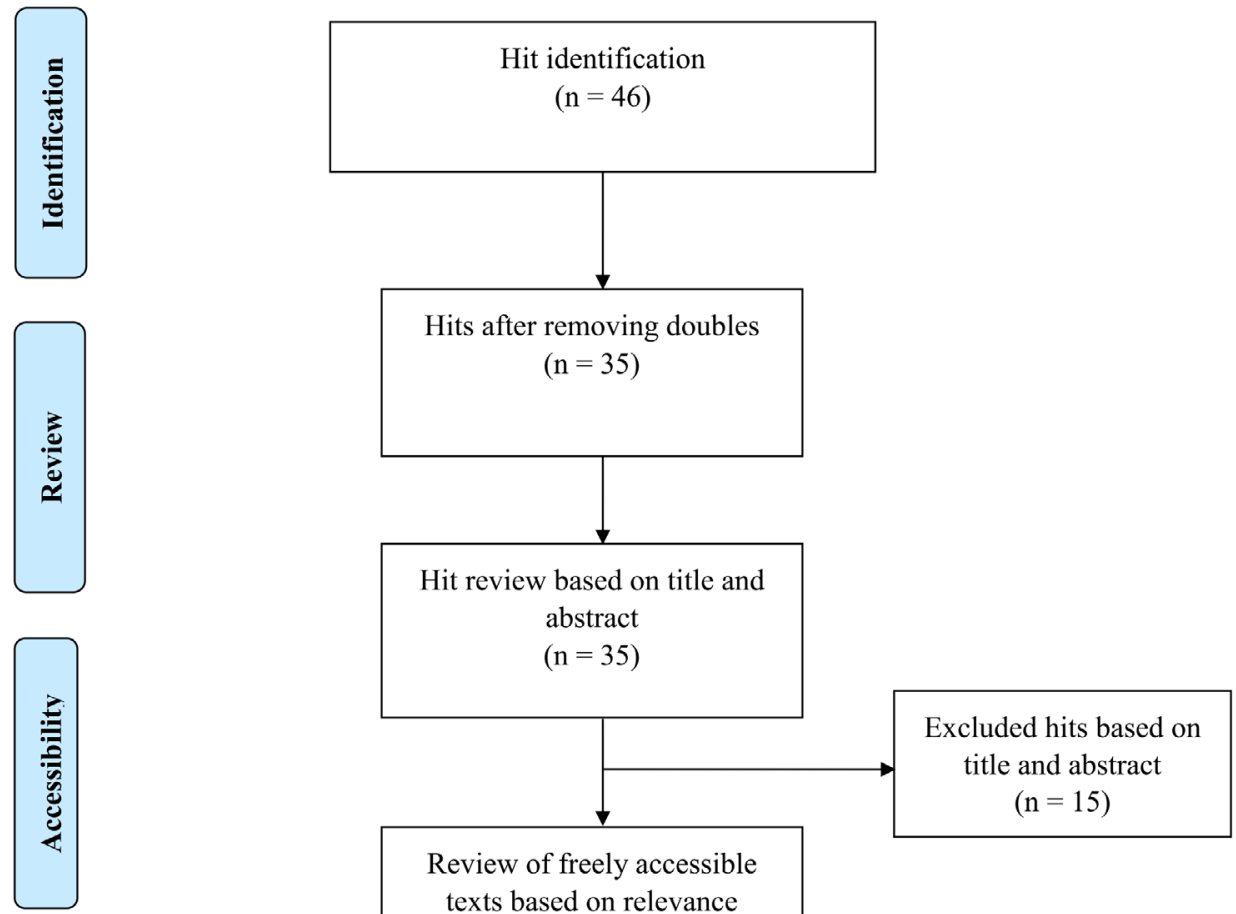
abstract $(\mathrm{n}=35)$

Hits included in review

$$
(\mathrm{n}=6)
$$

Figure 1: Results of the references review based on the PRISM

\section{Data processing description}

Data was analysed with the use of qualitative content analysis; according to Vogrinec (2008) open coding represents a key procedure of text analysis. A qualitative analysis was carried out in six steps, namely materials organising, coding, determining coding units based on key subject matter and purpose of systematic references review, selection and defining applicable key words and 
categories, defining categories and making conclusions by achieving a better understanding of the issues and needs of older employees.

\section{Results}

Table 1 shows all references included in materials review. Using qualitative content analysis of the acquired materials, three categories with applicable codes were identified (Table 2). The categories include: (1) The influence of rheumatic disease on absenteeism; (2) The importance of lifelong learning for the application of knowledge at work; (3) The measures for improving physical and mental health in all periods of life. In the following stage of materials review, the categories were changed into subcategories and a single category was formed. This category offers a comprehensive explanation of the purpose and objectives of materials review (Table 2 ).

Table 1: A review of the key findings of the research included in qualitative content analysis

\begin{tabular}{|c|c|c|c|c|}
\hline Author, year & Research typology & Research objective & Sample & Key findings \\
\hline Križanec, 2016 & $\begin{array}{l}\text { Qualitative re- } \\
\text { search }\end{array}$ & $\begin{array}{l}\text { To find out if there are sta- } \\
\text { tistically relevant differenc- } \\
\text { es in the quality of life of } \\
\text { patients suffering from in- } \\
\text { flammatory rheumatic dis- } \\
\text { ease treated with biological } \\
\text { medicines in comparison } \\
\text { to patients using standard } \\
\text { medicines; to find out to } \\
\text { what extent the disease can } \\
\text { influence absenteeism. }\end{array}$ & $\mathrm{n}=18 \mathrm{o}$ & $\begin{array}{l}\text { Patients taking biological } \\
\text { medicines have fewer ab- } \\
\text { sences from work; they as- } \\
\text { sess their quality of life } \\
\text { higher; a need for great- } \\
\text { er health-educational work } \\
\text { shown. }\end{array}$ \\
\hline Robnik, 2016 & $\begin{array}{l}\text { Quantitative re- } \\
\text { search }\end{array}$ & $\begin{array}{l}\text { To establish the presence } \\
\text { of elements of a learning } \\
\text { organisation and employ- } \\
\text { ees' viewpoints regarding } \\
\text { the introduction of train- } \\
\text { ing courses. }\end{array}$ & $\mathrm{n}=57$ & $\begin{array}{l}\text { Employees have demon- } \\
\text { strated a high level of moti- } \\
\text { vation for attending train- } \\
\text { ing courses. }\end{array}$ \\
\hline Lešnik, 2016 & $\begin{array}{l}\text { Quantitative re- } \\
\text { search }\end{array}$ & $\begin{array}{l}\text { To recognise the view- } \\
\text { points regarding acquir- } \\
\text { ing new knowledge and to } \\
\text { transfer knowledge from } \\
\text { the management to the } \\
\text { employees. }\end{array}$ & $\mathrm{n}=104$ & $\begin{array}{l}\text { Knowledge obtained in } \\
\text { training courses is put into } \\
\text { practice in the work place. }\end{array}$ \\
\hline $\begin{array}{l}\text { Topličanec, } \\
2018\end{array}$ & $\begin{array}{l}\text { Quantitative re- } \\
\text { search; case study }\end{array}$ & $\begin{array}{l}\text { To study the development } \\
\text { of health-related absen- } \\
\text { teeism and presenteeism; } \\
\text { to identify the limitations } \\
\text { of health promotion pro- } \\
\text { grammes (HPP). }\end{array}$ & $\mathrm{n}=198$ & $\begin{array}{l}\text { The HPP programme is fo- } \\
\text { cused on improving health } \\
\text { and includes preventive ac- } \\
\text { tivities. Own health con- } \\
\text { trol is enabled in working } \\
\text { environment; it reduc- } \\
\text { es health-related absentee- } \\
\text { ism and contributes to low- } \\
\text { er presenteeism. }\end{array}$ \\
\hline
\end{tabular}


To compare the frequency of physical exercise on the basis of age, gender and

Raduha, 2017 Descriptive qualitative research education level; to express viewpoints regarding the importance of regular exercise.

\section{Differences in gender, age and education level do not influence the level of physi- cal activity.}

\begin{tabular}{|c|c|c|c|c|}
\hline $\begin{array}{l}\text { Saje Zupanc, } \\
2015\end{array}$ & $\begin{array}{l}\text { Quantitative sur- } \\
\text { vey research }\end{array}$ & $\begin{array}{l}\text { To study a part of the life- } \\
\text { style of nurses and work- } \\
\text { place risk factors in ex- } \\
\text { plaining the incidence of } \\
\text { back pain. }\end{array}$ & $\mathrm{n}=461$ & $\begin{array}{l}\text { Back pain increases with } \\
\text { age; it is connected with } \\
\text { workplace stress and also } \\
\text { unhealthy lifestyle. Ergo- } \\
\text { nomic technical accessories } \\
\text { are underused in clinical } \\
\text { practice. It is vital to intro- } \\
\text { duce aerobic exercise and } \\
\text { take additional care of em- } \\
\text { ployees' physical health. }\end{array}$ \\
\hline
\end{tabular}

Table 2: Code allocation by category

Category Subcategories

categories

Codes

Author

The cooperation of nurses with rheumatic patients treated with

The influence of rheubiological medicines; the influmatic disease on absenteeism.

ence of biological medicines on Križanec, 2015

the quality of life; lower levels of absence from work, absenteeism; the presence of pain.

Factors which positively influence the decrease in absenteeism and presenteeism in (older) employees

\begin{abstract}
The importance of lifelong learning for applying new knowledge and skills in the work place.
\end{abstract}

Measures for improving physical and mental health in all life periods.
The importance of learning and knowledge for an individual and organisation; knowledge transfer; cross-generational cooperaRobnik, 2016; Lešnik, 2016 tion; innovativeness.

Education and training in the area of physical health maintenance; recognising negative ori- Raduha, 2017; entation towards physical ac- Topličanec, 2018; tivity; focused physical activity Saje Zupanc, 2015 in the workplace; coping with stressful situations.

\section{Discussion}

In the reviewed works, older employees are predominantly dealt with in that period of life when typically, due to various health issues and advanced age, they are no longer able to actively participate in the labour market. The health care of older employees, the development of social contacts, suitable communication, etc. are some of the research topics (Saje Zupanc, 2015; Raduha, 2017; Topličanec, 2018). The study of those segments of life which would allow an individual to keep an active role in society is carried out in "fragmental form " and is subordinate to other age groups. The society is faced with longevity, at the same time, Slovenia is a country that does not live according to the principles of active aging, as promoted by the European Union (Walker and Zaidi, 2016). 
In the research that was conducted as a part of her Master's thesis by Križanc (2016), absenteeism is presented as a consequence of an illness or insufficient results of treatment with conventional medicines. There are several studies at different post-graduate level programmes that deal with the phenomenon of absenteeism, yet only few at healthcare faculties. On the other hand, presenteeism, which has been recognised as a problem only recently, has not been researched in the scope that would provide a greater insight into finding specific solutions. Absenteeism and even more so presenteeism are often the consequence of fear of the »impossible" or »loss « and are harmful both for the employee and organisation, financially as well as medically (Vučković, 2010; Logar, 2011). Both phenomena are unacceptable: absenteeism also because it offers employees a possibility for abusing the sick leave system; and presenteeism, in which an employee understands that their medical state might be endangering to others but can be labelled as incapable, old and fit for retirement if they remain absent from work. Both society and the government need to introduce measures that will allow a person to be ill and recover in peace but at the same time prevent employees from abusing the system (Logar et al., 2015).

Taking care of health, by maintaining physical fitness and partially also managing stress, is dealt with in the reviewed materials without a special focus on older employees, which is confirmed also by other researchers (Logar, 2011; Ovčar, 2015; Jakop, 2016; Jagodič, 2019). The influences of psycho-social factors are not presented or rather they are not studied thoroughly enough, owning to their complexity and the fact that they are becoming the key causes of illness development. The connection between health and socio-economic position of older employees is key. Employees with lower levels of education, lower positions at work and lower income tend to suffer from cancer, cardio-vascular diseases and lower life expectancy (Manfreda, 2020). Preventive measures can go a long way in maintaining and improving people's health. They include various activities in health promotion programmes which are suitable for different generations (Saje Zupanc, 2015; Raduha, 2017; Topličanec, 2018).

One of the activities that helps to maintain good health is lifelong learning. The theses review demonstrated that many theses were prepared and studies carried out regarding learning organisation, the need for lifelong learning, passing the knowledge from generation to generation, which encourages cross-generational cooperation and strengthens knowledge of teams and organisations (Robnik, 2016; Lešnik, 2016).

Older employees already are or are about to become our reality. It is necessary to act in three ways: developmental strategy, management training, senior and junior staff training to achieve synergy - and in older employees also for quality aging before and after retirement (Ramovš et al., 2020).

The limitations of the survey conducted include a sample that is too small, owning to the fact that at healthcare faculties (Master's and Doctoral study) there is almost no published material about employment of older population, absenteeism and presenteeism. The phenomena of absenteeism and presentee- 
ism in connection with older employees are mentioned together with other topics of research but not directly. It is of vital importance that a more exhaustive study of this issue is conducted and that more Master's and Doctoral theses deal with the employment of older employees. Too often it happens that older employees are discriminated against in their workplaces, despite the fact that life expectancy is rising and labour force is shrinking.

\section{Conclusion}

Aging society and increasing longevity with all their implications have a considerable impact on the employment of older population. It is of vital importance for the medical field to start considering the necessity to prolong the active service of employees. Modern times dictate research into older employees on the academic level since progress largely depends on the inclusion of all people in all their diversity.

\section{References}

BILBAN, M., 2007. Promocija zdravja na delovnem mestu za zmanjševanje absentizma. Ljubljana: Zavod za varstvo pri delu.

BOŠTJANČIČ, E. and SAJINČIČ, N., 2016. Prezentizem - žulj slovenskih delodajalcev, HR\&M, vol. 2, no. 3, pp. 64-67.

BREČKO, D., 2012. Prezentizem in delo. Na delu, toda v resnici odsotni. Human Resource Management Magazin, vol. 45, pp. 32-36.

GASPARI, M., 2020. Ekonomsko-politične dileme Evropske unije. Dnevnik. Ljubljana: Dnevnik, družba medijskih vsebin, d. d., 26. 6. 2020, p. 14.

JAKOP, T., 2016. Organizacija dela in z njo povezan stres na delovnem mestu dispečerja v splošni nujni medicinski pomoči: master thesis. Maribor: Univerza v Mariboru, Fakulteta za zdravstvene vede, pp. 21-33.

JAGODIČ, M., 2019. Identifikacija stresorjev na področju dela radioloških inženirjev: master thesis. Ljubljana: Univerza v Ljubljani: Zdravstvena fakulteta, pp. 7-27.

KRIŽANEC, S., 2016. Vpliv vnetne revmatološke bolezni na absentizem in kakovost življenja pri bolnikih, zdravljenih z biološkimi zdravili: master thesis. Maribor: Univerza v Mariboru, Fakulteta za zdravstvene vede, pp. 23-33.

LALIĆ, H. and HROMIN, M., 2012. Presenteeism Towards Absenteeism: Manual Work Versua Sedentary Work, Private versus Governmental - A Croatian Review. Collegium antropologicum, vol. 36, no. 1, pp. 111-116.

LEŠNIK, M., 2016. Management človeških virov v učeči se organizaciji: master thesis. Maribor: Univerza v Mariboru, Fakulteta za zdravstvene vede, pp. 23-33.

LOGAR, M., 2011. Dejavniki stresa na delovnem mestu in njihov vpliv na zdravstveni absentizem: master thesis. Koper: Univerza na Primorskem, Fakulteta za management Koper, pp. 35-53. 
LOGAR, M., KODRIČ, B., PAVLIČ, M. and MARKIČ, M., 2015. Dejavniki stresa na delovnem mestu in njihov vpliv na zdravstveni absentizem. In: TARADI, J., ed. Management and safety: [proceedings]: M\&S 2015: conference theme: Stress management and safety: program cycle: Modern management concepts and safety:1oth international conference, Opatija, Croatia, June 12th and 13th, 2015. [Zagreb]: European Society of Safety Engineers, pp. 37-45.

LOGAR ČUČEK, M., 2020. Starejši zaposleni v »novih časih«. Obrtnik podjet$n i k$, vol. XLIX, no. 5, pp. 24-25.

MANFREDA, I., 2020. Psihosocialni dejavniki postajajo odločujoči dejavnik za nastanek bolezni [online]. [viewed 28 June 2020] Available at: https:// www.bogastvozdravja.si/zdravje-in-lepota/zdravo-zivljenje/889-psihosocialni-dejavniki-postajajo-odlocujoci-dejavnik-za-nastanek-bolezni.

MOHER, D., LIBERATI, A., TETZLAFF, J., ALTMAN, D.G. and PRISMA GROUP, 2009. Preferred reporting items for systematic reviews and meta-analyses: The PRISMA Statement. PLoS Medicine, vol. 6., no. 7, pp. 1-6.

NOVOSELC, J., 2019. Vključi modrost za aktivno starost. In: Aktivno in zdravo staranje zaposlenih - priložnost za gospodarstvo: zbornik prispevkov/ strokovna konferenca POLETpozdrav aktivnim 2019, Maribor, maj 2019 [online]. Maribor: Polet, pp. 24-26. [viewed 24 June 2020] Available at: https://projekt-polet.si/wp content/uploads/2019/05/Polet_Zbornik_1_ uvodna-strokovna-konferenca.pdf.

OVČAR, M., 2015. Izgorevanje in stres pri medicinskih sestrah v dializnih centrih: master thesis. Maribor: Univerza v Mariboru, Fakulteta za zdravstvene vede, pp. 5-43.

RADUHA, E., 2017. Spodbujanje telesne aktivnosti za zdravje vseh generacij: master thesis. Maribor: Univerza v Mariboru, Fakulteta za zdravstvene vede, pp. 5-38.

RAMOVŠ, J, RAMOVŠ, K, GREBENŠEK, T., GORENC VUJOVIĆ, A. and OGRIN, A., 2019. Aktivno in zdravo staranje - prakse in zakonodaja [online]. Ljubljana: Inštitut Jožeta Trstenjaka [viewed 28 June 2020]. Available at: https://projekt-polet.si/wp-content/uploads/2019/07/\%C5\%Aotudijaza-GZS-Aktivno-zdravo-staranje-PRAKSE-ZAKONODAJA-jan-2019x.pdf.

ROBNIK, P., 2016. Uvajanje koncepta učeče se organizacije v regijsko bolnišnico: master thesis. Maribor:

SAJE ZUPANC, 2015. Povezave med življenjskim slogom in dejavniki tveganja na delovnem mestu s pojavom bolečine v križu pri medicinskih sestrah na travmatoloških in ortopedskih oddelkih: master thesis. Jesenice: Fakulteta za zdravstvo, 10-26.

TOPLIČANEC, P., 2018. Evalvacija programov promocije zdravja na delovnem mestu $v$ slovenskih vrtcih: master thesis. Ljubljana: Univerza v Ljubljani, Zdravstvena fakulteta, pp. 7-33. 
TRATNIK, E., 2019. Varnost in zdravje pri delu za delavce vseh generacij. In: Aktivno in zdravo staranje zaposlenih - priložnost za gospodarstvo: zbornik prispevkov/strokovna konferenca POLETpozdrav aktivnim 2019, Maribor, maj 2019 [online]. Maribor: Polet, pp. 24-26. [viewed 24 June 2020] Available at: https://projekt-polet.si/wp content/uploads/2019/05/Polet_Zbornik_1_uvodna-strokovna-konferenca.pdf.

VAN DALEN, H. P., HENKENS K. and WANG M., 2015. Recharging or Retiring Older Workers? Uncovering the Age-Based Strategies of European Employers [online]. The Gerontologist, vol. 55, no. 5, pp. 814-824. [viewed 25 June 2020] Available at: https://doi.org/10.1093/geront/gnuo48.

VOGRINC, J., 2008. Kvalitativno raziskovanje na pedagoškem področju. Ljubljana: Univerza v Ljubljani. Pedagoška fakulteta.

VUČKOVIĆ, R., 2010. Obvladovanje zdravstvenega absentizma - izziv za družbo. In: KOS, D., eds. Zdravstveni absentizem v Sloveniji: zbornik primerov iz prakse 14 slovenskih podjetij. Ljubljana: Zavod za zdravstveno zavarovanje Slovenije, pp. 10-20.

WALKER, A. and Zaidi, A., 2016. New evidence on active ageing in Europe. Intereconomics: review of European Economic Policy, vol. 51, no. 3, pp. 139144.

WARGO-SUGLERIS M., ROBBINS W., LANE C.J and PHILLIPS L.R., 2018. Job satisfaction, work environment, and successful aging: determinants of delaying retirement among acute care nursis [online]. Journal of Advanced Nursing, vol. 74, no. 4, pp. 900-913. [viewed 26 June 2020]. Available from: http://dx.doi.10.1111/jan.13504 